\title{
Econometric Estimation of Seasonal Differences between these Products, Apples and Tomato in Focus the Region of Prizren, Korca and Lushnja
}

\section{Eriona Deda}

\author{
PhD Student, Faculty of Economics and Agribusiness,
} Agricultural University of Tirana

\section{Doi:10.5901/ajis.2017.v6n1p67}

\section{Abstract}

In our study we chose some areas, mainly the Korça, Lushnja, and Prizren areas. We have handled seasonal differences in the product of apple and tomato. And the impact of these seasonal differences in work-occupation of farmers on farm over a year in the activity of apple or tomato, in income, sale and prices. In the Korça area will treat the impact of seasonal differences in work -occupation of farmers on activity of apple, and the impact of these differences in income, sales and price for Korça area. For Lushnja area will treat the influence of seasonal differences in the case of tomatoes. And in the area of Prizren will treat impact of seasonal differences in the case of apple and tomato. Assessment of the seasonal differences by regions and products that we have taken in the study will be the basis of some econometric models, by using Eviews programme.

Keywords: seasonal differences, work-occupation, income, price, sale

\section{Introduction}

In this paper will treat econometric evaluation of seasonal differences in apple for Korça region , in tomatos for Lushnja region, and in apple and tomatoes for Prizren region.

Also we will treat seasonal impact of these differences in these economic phenomena, work-occupation of farmers over a year in the activity of apple or tomato, price fluctuations, income and the sales of these products by quarters in the areas that we have considered in this study. Regions that have taken in the study are:

1. Lushnja area (for the cultivation of tomatoes) which is characterized by the potential production of vegetables in the country. Mainly the production of tomatoes in protected environments, in greenhouses. However Lushnja farmers to cultivate tomatoes in environments protected facing a lot of problems as a result of the impact of adverse seasonal volatility of the price of tomatoes, lack of market sure which is reflected in the low income of farmers from selling tomatoes etc.

2. Prizren area (for the cultivation of tomatoes and apples)

Tomato cultivation in Kosovo, mainly in the region of Prizren is implemented in the open field and in protected environments, but recently there is a persistent tendency to move towards cultivation in protected environments.

3. The Korça area (for the cultivation of apple) is one of the most popular areas of Albania on the quality of apple production and cultivation.

The apples production period is January - February and October - December, but its production potential and storage capacity in the area provide qualitative market supply throughout the year.

One of the problems facing the farmers of Korca to exercise their activity in apples it is:

$>$ The lack of protective systems from hail

\section{The Research Problem}

Seasonal effects are mainly reflected in these economic phenomenon: In fluctuation prices of tomatoes throughout the year, especially in the prices of imports, sale, income and in work-occupation of farmers in tomato activity by quarters.

Regarding apple, apple in Kosovo is quite a culture traditionally cultivated as a result of favorable climatic conditions.

Market apples in the Prizren region is a market for which there is a large enough demand, but Kosovo does not 
meet the requirement of customers with local production of apple product throughout the year.

Some problems which remain challenges for farmers to deal with the cultivation of apples are:

$>$ Lack of quality seedlings produced according to the highest international standards,

$>$ old orchards, machinery amortized

$>$ lack of storage for the storage, processing process is in its infancy etc.

\section{The Aim of the Research Problem}

The Aim of the Research Problem is to determine the factors that cause seasonal differences on economic phenomena which are expressed more, in work-occupation, price, income or sale, and measures by farmers to make predictions about production as well as support from the government through investments to reduce as much as possible negative effects of seasonal differences on economic phenomena that we have taken in the study.

\section{Data}

\subsection{Secondary Data}

Sources with important information from where we collected secondary data are:

INSTAT, the statistics office for the district of Korca, Lushnja.

INSTAT, the statistics office for the district of Prizren.

Libraries, from which we have exploited the selected bibliography.

\section{Production which Includes (Offer for Apple, Tomato)}

Income (whole farm)

work-occupation (whole farm)

The data have analyzed the Year-2012 to 2015, for the region of Lushnja, Korca and Prizren. The data of economic time series are analyzed relying on seasonal variations.

- Primary

- Formation of sample

Primary data will be provided through questionnaires completed in connection with the farm selected for these regions.

1. Prizren (apple, tomato)

2. Korçe (apple)

3. Lushnja (tomatoes)

1. In Prizren area, will receive 100 questionnaires (survey) from some farms in Prizren in connection with seasonal differentiation in work-occupation, manufacturing, sales, prices and farm incomes in general in activity of apples and tomatoes.

2. In Korça area, will receive 100 questionnaires (survey) by some farmers in connection with the seasonal differentiation in work-occupation, manufacturing, sales, prices and farm incomes in general in apples activity.

3. In Lushnja area, will receive 100 questionnaires (survey) by some farmers in connection with the seasonal differentiation in work-occupation, manufacturing, sales, prices and farm incomes in general in tomatoes activity.

The information that we receive for variables by means of questionnaires carried out through a Likert scale; that we see quantitative assessments regarding the extent and seasonal distribution of the effects on:

- Farm work-occupation

- Income

- Prices

- Sales

- Production

\section{Method of Sampling}

We will use the technique of choice accidental.

This technique makes possible a better choice which also gives us the opportunity to make a big impact with a 
base orientation very good reliability.

Dummy variables are often used in time series analysis, the seasonal and qualitative analysis to data applied. A simple way to assess the seasonal effects in a time series through dummy variables.

We must use dummy variables, one for each quarter, or three and a constant dami. These variables use them as inputs or factors in a regression model.

\section{The Analysis and Findings}

\subsection{Analysis of regional and seasonal differences between apple-tomato products}

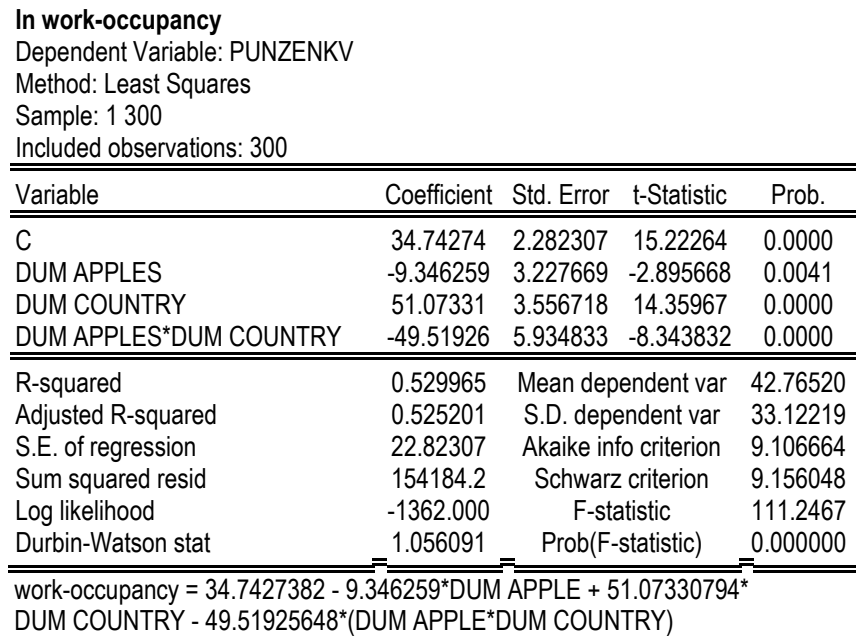

\subsection{Interpretation}

Between apple and tomato has significant differences to seasonal effects. In apple the seasonal effects are 9.3 units smaller than in tomato.

Between Albania and Kosovo has significant differences to seasonal effects;

In Kosovo seasonal effects are 51 units larger. Also and interplay between country * product is sinjifkant, with negative effect of 49.5 points.

\begin{tabular}{lcccc}
$\begin{array}{l}\text { In sale } \\
\text { Dependent Variable: Sale CV } \\
\text { Method: Least Squares }\end{array}$ & & & & \\
Sample: 1300 & & & & \\
Included observations: 300 & & & & \\
\hline \hline Variable & Coefficient & Std. Error & t-Statistic & Prob. \\
\hline \hline C & 45.67256 & 2.117809 & 21.56595 & 0.0000 \\
DUM APPLES & 31.84628 & 2.995034 & 10.63303 & 0.0000 \\
DUM COUNTRY & 49.48170 & 3.300367 & 14.99279 & 0.0000 \\
DUM APPLES*DUM COUNTRY & -41.55552 & 5.507079 & -7.545837 & 0.0000 \\
\hline \hline R-squared & 0.464808 & Mean dependent var & 71.81096 \\
Adjusted R-squared & 0.459383 & S.D. dependent var & 28.80329 \\
S.E. of regression & 21.17809 & Akaike info criterion & 8.957055 \\
Sum squared resid & 132759.4 & Schwarz criterion & 9.006439 \\
Log likelihood & -1339.558 & F-statistic & 85.69076 \\
Durbin-Watson stat & 1.261602 & Prob(F-statistic) & 0.000000 \\
\hline \hline
\end{tabular}

$\overline{\overline{\text { Sale CV }=45.67255735+31.846282}}=\overline{\overline{18^{*} \mathrm{DUM} A}}=\overline{\overline{\mathrm{PLE}+49.48169737^{*}}}$

DUM COUNTRY - 41.55552367*(DUM APPLE*DUM COUNTRY) 


\subsection{Interpretation}

Between apple and tomato has significant differences to seasonal effects. In apple the seasonal effects are 31.8 units larger than in tomato.

Between Albania and Kosovo has significant differences to seasonal effects;

In Kosovo seasonal effects are 49 units larger. Also and interplay between country * product is sinjifkant, with negative effect of 41.5 points.

\begin{tabular}{|c|c|c|c|c|}
\hline Variable & Coefficient & Std. Error & t-Statistic & Prob. \\
\hline $\begin{array}{l}\text { C } \\
\text { DUM APPLES } \\
\text { DUM COUNTRY } \\
\text { DUM APPLES*DUM COUNTRY }\end{array}$ & $\begin{array}{l}121.0947 \\
52.27597 \\
-37.19240 \\
42.73575\end{array}$ & $\begin{array}{l}1.451716 \\
2.053036 \\
2.262336 \\
3.774993\end{array}$ & $\begin{array}{c}83.41490 \\
25.46276 \\
-16.43982 \\
11.32075\end{array}$ & $\begin{array}{l}0.0000 \\
0.0000 \\
0.0000 \\
0.0000\end{array}$ \\
\hline $\begin{array}{l}\text { R-squared } \\
\text { Adjusted R-squared } \\
\text { S.E. of regression } \\
\text { Sum squared resid } \\
\text { Log likelihood } \\
\text { Durbin-Watson stat }\end{array}$ & $\begin{array}{r}0.867119 \\
0.865772 \\
14.51716 \\
62381.38 \\
-1226.267 \\
1.636014\end{array}$ & $\begin{array}{c}\text { Mean dep } \\
\text { S.D. dep } \\
\text { Akaike in } \\
\text { Schwarz } \\
\text { F-st } \\
\text { Prob(F- }\end{array}$ & $\begin{array}{l}\text { endent var } \\
\text { endent var } \\
\text { fo criterion } \\
\text { c criterion } \\
\text { atistic } \\
\text { statistic) }\end{array}$ & $\begin{array}{l}135.6238 \\
39.62418 \\
8.201783 \\
8.251167 \\
643.8519 \\
0.000000\end{array}$ \\
\hline
\end{tabular}

\subsection{Interpretation}

Between apple and tomato has significant differences to seasonal effects. In apple the seasonal effects are 52.2 units larger than in tomato.

Between Albania and Kosovo has significant differences to seasonal effects;

In Kosovo seasonal effects are 37 units smaller. Also and interplay between country * product is sinjifkant, with positive effect of 42.7 points.

In prices

Dependent Variable: Prices CV

Method: Least Squares

Sample: 1300

Included observations: 300

\begin{tabular}{|c|c|c|c|c|c|}
\hline Variable & & Coefficient & Std. Error & t-Statistic & Prob. \\
\hline C & & 55.02804 & 3.905544 & 14.08973 & 0.0000 \\
\hline DUM APPLES & & 79.95393 & 5.523273 & 14.47582 & 0.0000 \\
\hline DUM COUNTRY & & 24.59097 & 6.086350 & 4.040347 & 0.0001 \\
\hline DUM APPLE*DUM & COUNTRY & -6.829734 & 10.15584 & -0.672493 & 0.5018 \\
\hline R-squared & & 0.490571 & \multicolumn{2}{|c|}{ Mean dependent var } & 97.18876 \\
\hline Adjusted R-squared & & 0.485408 & \multicolumn{2}{|c|}{ S.D. dependent var } & 54.44398 \\
\hline S.E. of regression & & 39.05544 & \multicolumn{2}{|c|}{ Akaike info criterion } & 10.18108 \\
\hline Sum squared resid & & 451496.9 & \multicolumn{2}{|c|}{ Schwarz criterion } & 10.23047 \\
\hline Log likelihood & & -1523.163 & \multicolumn{2}{|c|}{ F-statistic } & 95.01413 \\
\hline Durbin-Watson stat & & 1.134602 & \multicolumn{2}{|c|}{ Prob(F-statistic) } & 0.000000 \\
\hline
\end{tabular}

Prices CV = 55.0280402 + 79.9539309*DUM APPLE + 24.59096637*

DUM COUNTRY - 6.829734471*(DUM APPLE *DUM COUNTRY) 


\subsection{Interpretation}

Between apple and tomato has significant differences to seasonal effects. In apple the seasonal effects are 79.9 units larger than in tomato.

Between Albania and Kosovo has significant differences to seasonal effects;

In Kosovo seasonal effects are 24.5 units larger. Also and interplay between country * product is sinjifkant, with negative effect of 6.8 points.

Note here

The interaction effect country *product is not significant!

\section{Conclusion and Recommandations}

Through this paper we have point out the impact of seasonal effects in these economic phenomena, in work-occupation, income prices and sales of farmers for Korça, Lushnja and Prizren areas in tomatos and apples activity.

Also we have treat econometric evaluation of seasonal differences in apple for Korça region , in tomatos for Lushnja region, and in apple and tomatoes for Prizren region.

Also we defined the relationship between variables of model and significance of seasonal effect for each of products and quarters for Korça,Lushnja and Prizren areas.

We used dummy variables method for econometric estimation.

\section{References}

M. Osmani , Moduli Ekonometri me zbatime , Universiteti Bujgesor i Tiranes, Analiza ekonometrike me ndryshore dummy, fq 129-130, Tirane 2010

Richard. A. Davis, Indicator Variables for Seasonal Time Series, Department of Statistics. http://ëë.stat.columbia.edu/ rdavis/lectures/ Session6.pdf, chapter 13

Osmani. M, Econometric Module, Agricultural University of Tirana, The multiple model of regression, page 49,Albania 2002

Osmani. M, Econometric Module, Agricultural University of Tirana, calculation of $R^{2}$ and R, page 54,Albania 2002

M. Osmani, Methods of econometrics with EViews 7, programme, Agricultural University of Tirana, Albania. 